\title{
Hotel Management Strategy in Surakarta City in Supporting Eco-Tourism Concept
}

\author{
Dicky Sumarsono \\ Program Pasca Sarjana Ilmu \\ Budaya \\ Universitas Sebelas Maret \\ Surakarta, Indonesia \\ dickysumarsono@gmail.com
}

\author{
Bani Sudardi \\ Jurusan Sastra Indonesia \\ Universitas Sebelas Maret \\ Surakarta, Indonesia \\ banisudardi@yahoo.co.id
}

\author{
Warto Warto \\ Jurusan Sejarah \\ Universitas Sebelas Maret \\ Surakarta, Indonesia \\ warto_file@yahoo.co.id
}

\author{
Wakit Abdullah \\ Program Pasca Sarjana Ilmu \\ Budaya \\ Universitas Sebelas Maret \\ Surakarta, Indonesia \\ abdullahwakit@yahoo.com
}

\begin{abstract}
This study aims to analyze and express the effort of hotel management through simplicity, treating to the genuineness of nature and environment and treating to the genuineness of art and culture. Hotel in Solo has important role in the concept of eco tourism, because hotel is facility for tourists who visit Solo. Method of this study is explorative qualitative with cultural studies based on enthnography approach. The location was Solo with data were taken through deeply interview to the related parties of tourism and hotel. Research secondary data is needed through researchers' observation, document, and policies toward hotel management strategy in Surakarta related to the concept of eco tourism. To test data validity the researchers do triangulation in every meeting. Result of the study are several activities of hotel management in Solo are already eco tourism such as hotel architecture, eco friendly hotel management, appropriate hotel concept towards Solo people socio culture. Currently Solo is one of tourism destinations in central java, supported by representative hotel for domestic and international guess. Hotel's ambiance reflects local wisdom and Solo people's habit have created serenity, maintaining beautiful ornamental plants which guarantee conserved living environment resulting the equilibrium between human and environment.
\end{abstract}

Keywords-hotel management; eco-tourism; environment

\section{INTRODUCTION}

One of the development of responsible tourism is marked by the inclination of tourists who utilize the eco-friendly tourism product. This pushes the alteration of tourist consumption pattern including in taking benefit of eco-tourism especially hotel. Currently tourist is smarter and more selective for really choosing hotel which is really consistent applying green hotel by utilizing resources based on local product or which is associated in green industry such as Eco green Hotel, Eco Suites, Green Hotel Association [1].

The movement of back to nature which is currently held by non-governmental organization (NGO) and some experts of living environment basically is an opportunity for the developer of eco-tourism in Indonesia. Hotel Industry in
Surakarta has opportunity and important role in developing eco-tourism. The concept of green hotel is a mandate of UU number 10 of 2009 about tourism and the guidance book of green hotel 2015 expresses eco-tourism product as a must for the managements of hotel to manage their business. Because the concept of green hotel has the value of long term investment which are able to create tourist loyalty, management reputation, saving operational cost, creating relation to the local community and able to create health management [2].

The application of green hotel as an important component in eco-tourism determines the continuity of hotel business, even for the management is not only doing nature conservation, cultural preservation and taking care of the equilibrium, however with the eco-tourism the management is able to save the operational cost and creates good management reputation. The product of eco-tourism has supporting role of hotel business in helping to improve resource efficiency and as a strengthener of competitiveness because hotel can take role as tourism attraction and also as the connector which is able to create good image and reputation of the management [3].

According to Yoeti [4] and Ferianto, Darsiharjo and Rahmafitria [5] the implementation of eco-tourism has difference to the common tourism. Eco-tourism does not demand the availability of modern and glamorous facility of accommodation which is completed by luxurious equipment and also over artificial building, but eco-tourism is applied by simplicity, genuineness of nature, genuineness of culture and art, and protected living environment until created equilibrium between human and nature surrounding. Based on it, the question of proposed research is how the role of strategy of hotel management in improving eco-tourism in Surakarta?

\section{RESEARCH PURPOSE}

This study is aimed to explain the role and strategy of hotel management in developing eco-tourism to create competitiveness of Surakarta. The benefit of this research can give information to develop hotel business and also tourism sector of Surakarta by giving attention to the competitiveness. 


\section{RESEARCH METHOD}

The method of this research is explorative qualitative with cultural studies based on enthnography approach [6][7][8]. The processes are (1) collecting data (2) analyzing data (3) presentation of the result of analyzing data [9]. The location of this study was Surakarta city, the data was taken through deeply interview with key informant with the parties related to tourism and hotel. The secondary data of the research is needed through the observation of researchers, document and the policy toward the strategy of hotel management in Surakarta related to the concept of eco-tourism. Document study was done to get written materials, text books, journals, magazines, research reports, relevant newspapers towards research problem to test the validity to do triangulation in every meeting.

\section{THE PERSPECTIVE OF HOTEL MANAGEMENT TOWARDS ECO- TOURISM CONCEPT}

Eco-tourism is one of tourism form which responsible to the sustainability to the area which is still natural, giving economical benefit and maintaining cultural integrity for the local community. Based on the mentioned definition, basically the form of eco-tourism is a form of conservation movement [10]. Eco-tourism is translated as ekowisata, as an environmentally sound tourism. Tourists are invited to see the nature closely, enjoying the genuineness of nature and environment to make them loving nature with the term of Back-to-Nature. Different to the common popular tourism, the implementation of eco-tourism does not sue to the availability modern or glamour facilities of accommodation completed by luxurious equipment and over artificial building. Some hotels which develop eco-tourism such as Lor Inn Hotel, d' Green Kayon Airport Hotel, Gambir Anom hotel (Azhima), which is located in the edge area of Surakarta.

According to Purwanto Yodhonegara, The General Manager of Lor Inn Hotel, basically in the implementation of eco-tourism through simplicity, maintaining the genuineness of nature and environment, maintaining the genuineness of art and culture, customs, the way of life, creating calmness, solitude, taking care of flora and fauna, and also conserved living environment to create equilibrium between human and nature surrounded. Eco-tourism is a kind of tourism which can improve knowledge, expanding insight, learning from the nature, flora and fauna, socio-cultural and local ethnic. In ecotourism there are four important aspects such as: pro active, the concern of the conservation of living environment, the involvement of local community, and educational aspect. The visiting tourist is not only enjoying the nature around but also learning to improve knowledge and experience.

Meanwhile, the supervisor marketing of d'Green Kayon Airport Hotel Supriyono stated that historically, the reason of tourist for the reservation to hotel based on eco-tourism because of the scarcity of natural scenery, ease of recreation. Eco-tourism is developing along the last decade as the reaction of the changing of tourism industry which is tend to sell luxurious modernity. That is why eco-tourism is very important for the progress of ecology, sociology, and the continuity of hotel industry suit to the demand of hotel consumer. Along the last several decades, the awareness improvement of conservation and biodiversity has produced new approach which is developing by hotel management as tourism product.

\section{HOTEL'S STRATEGY DEVELOPING ECO-TOURISM}

\section{A. Hotel as Eco-Tourism Agent}

Managerially, the main activity is selling the room, however the intensity which is directly connected to the tourists, hotel has role as an agent. Tourists who stay in the hotel when they need any information about any eco-tourism destinations is served by formed traveling special service to the eco-tourism places. For example, d'Green Kayon Airport hotel serves traveling to Kemuning, Tawangmangu, Selo, Rafting in Magelang and Kedungombo, etc. Lor Inn and Oshima Hotel also serve traveling to eco-tourism in Soloraya, Magelang and Salatiga. The tourists' limited information related to time, cost, and distance become the hotel management's consideration to open special service as the connector, as well as for the provider of tourism product or tourism market. Hotel management also has a role as marketer of tourism product. The function as marketer will be helped with the principles of continuity and the more responsible programs until it is able to provide positive impression from the tourists.

\section{B. Developing Sustainable Tourism Development Concept}

Hotel management develops eco-tourism by conserving local wisdom which has natural destination by introducing local culture as an educational means for tourists. Hotel management has very important role for certain destinations to get better quality of tourists and able to help local communities to promote culture and presents the value of their local wisdom [11]. The development of local economic is not only to support continuity of the conservation but also to support the prosperity of the local communities. However in developing and reinforcing the concept of eco-tourism to develop local economic there is a need of an appropriate understanding for the local communities and government. This is to make local government and communities to take active role and become the stakeholder which has interest towards the development of the local area.

The principle of ecology continuity oftenly reputed just only to minimize the impact. This philosophy basically of the acceptance that there will be impacts from the tourism. The effect directs to the long term negative ecological consequences which does not have continuity. All the tourism activity is highly depended on the nature, not only eco-tourism and tourism based nature which is depended on natural sources. The concept of sustainable tourism development especially related to the aspects of tourism marketing. The development of sustainable tourism expands and also colors the specific concept of tourism marketing.

The emphasis of eco development which is developed in d'Green Kayon Airport Hotel and Oshima Hotel with the concept of admitting environmental interdependence, economic, and social. This strategy is taken through the 
development of resort in the environment of the hotel because of having proper area. The development of the resort is to guarantee the tourism resources (nature or man made) in the long term condition. Tourism has strong dependency towards high quality natural resources, therefore green tourism actually is not only an ideal but it is a must of economic, this is make sense, good economic will grow up from the ability of taking care environment, environment as resources which gives opportunities to be used by business people compatibly.

\section{Green Tourism Marketing}

Green marketing is a process of holistic management and responsible to satisfy the customers need, society, stake holder, and natural environment. Green marketing is eco friendly promotion process by selling new life style which contribute to the reasonable economic and ecology [12]. In marketing, whatever the product is, the ending is the customer satisfaction, customer retention and long term continuity. The tourism marketing can not be avoided from those four importances. Therefore, the value of continuity in the marketing of tourism is the totality of the price planning system. The promotion of green tourism pushes the continuity through selective process in the development of marketing program to attract tourist who aware of the environment.

A destination is proper called as green tourism if it is has four dimensions such as: natural basic, conservation support, sustainable and environmental education [13][14]. Therefore green tourism is the kind of tourism which has the best layout to get learning experience and sustainable appreciation in managing and improving environmental sustainability, culture, social, and resources of destination and promoting life sustainability which is more in quality.

As taken by the management of Lor Inn Hotel in the marketing of green tourism, such as: (1) revitalizing and corservating the environment area around the hotel, (2) revitalizing and corservating history and culture of Keraton Solo in the term of cooperation as Pemangku Keraton, (3) empowering local community through CSR in tourism area for the sustainability of the environment and giving attention to the developed destination place.

\section{CONCLUSION}

The result of the study is several activities from the hotel management in the city of Solo there are many of them applying eco-tourism such as design and architecture of the hotel, hotel management which is eco friendly and the concept of hotel which proper to the socio culture of Surakarta citizen. Currently, Solo still one tourism destination in Central Java, with the support of hotel facilities which is representative to domestic and international tourists. The ambience of hotel which reflects local wisdom and way of life of people of Solo has created serenity by taking care of beautiful ornamental plants, which guarantee conserved living environment resulting the equilibrium between human and environment.

\section{REFERENCES}

[1] N. J. Sinangjoyo, "Green Hotel sebagai Daya Saing Suatu Destinasi: Studi Kasus pada Industri Hotel Berbintang di Wilayah Yogyakarta," J. Nas. Pariwisata, vol. 5, no. 2, pp. 83-93, 2013.

[2] Kementerian Pariwisata, Buku Pedoman dan Panduan Pelaksanaan "Green Hotel" di Indonesia. Jakarta: Kementerian Pariwisata Republik Indonesia, 2016.

[3] H. Han, L. T. (Jane) Hsu, and J. S. Lee, "Empirical investigation of the roles of attitudes toward green behaviors, overall image, gender, and age in hotel customers' eco-friendly decision-making process," Int. J. Hosp. Manag., vol. 28, no. 4, pp. 519-528, 2009.

[4] O. Yoeti, Pemasaran Pariwisata. Bandung: Angkasa, 2000.

[5] A. R. D. Ferianto, Darsiharjo, and F. Rahmafitria, "Pengaruh Konsep Green Hotel Terhadap Minat Berkunjung Wisatawan ke Kota Bandung," Antol. Manaj. Resort Leis., vol. 2, no. 2, pp. 1-9, 2014.

[6] M. B. Miles, A. M. Huberman, and J. Saldana, Qualitative Data Analysis: A Methods Sourcebook Edition third. Los Angeles: SAGE Publications, 2014.

[7] I. Dey, Qualitative Data Analysis: A user-friendly guide for social scientists. London: Routledge, 1993.

[8] P. Alasuutari, Researching Culture: Qualitative Method and Cultural Studies. London: SAGE Publications, 1995.

[9] R. C. Richey and J. D. Klein, Design and Development Research: Methods, Strategies, and Issues. New Jersey: RoutledgeFalmer, 2007.

[10] R. Buckley, Ecotourism: Principles and Practices. Oxfordshire: CAB International, 2009.

[11] D. Crouch and S. McCabe, "Culture, Consumption and Ecotourism Policies," in Ecotourism Policy and Planning, D. A. Fennell and R. K. Dowling, Eds. Wallingford: CAB International, 2003, pp. 77-98.

[12] G. M. Carter, M. P. Murray, R. G. Walker, and W. E. Walker, Building Organizational Decision Support Systems. Boston, MA: Academic Press, 1992.

[13] T. Knowles, S. Macmillan, J. Palmer, P. Grabowski, and A. Hashimoto, "The Development of Environmental Initiatives in Tourism: Responses from the London Hotel Sector," Int. J. Tour. Res., vol. 1, pp. 255-265, 1999.

[14] T. Mihalič, "Environmental management of a tourist destination: A factor of tourism competitiveness," Tour. Manag., vol. 21, no. 1, pp. 65-78, 2000. 